Ks. DZIEKAN WYDZIAŁU HISTORII KoŚCIOŁA PAT JANUSZ WYCISŁO

\title{
KSIĄDZ PROFESOR JAN ZWIĄZEK SYLWETKA UCZONEGO Z PERSPEKTYWY JUBILEUSZU
}

Ośrodek naukowy, jakim jest uniwersytet lub akademia, to miejsce, w którym zawiązują się trwałe więzi przyjaźni i koleżeństwa. Dzieje się tak z tego względu, że tutaj nie tylko wspólnie poszukuje się prawdy, ale formułuje się też wspólnota osób. Trwa ona, choć lata studiów szybko biegną, ponieważ na fundamencie tej samej pasji poznawczej dochodzi do spotkania tych, którzy ją wspólnie dzielą. W środowisku akademickim sposobem wyrażania przyjaźni, szacunku i życzliwości wobec Mistrza, Przyjaciela bądź Kolegi jest ofiarowanie Mu księgi pamiątkowej.

W roku 1997 Wyższa Szkoła Pedagogiczna w Częstochowie wydała księgę pamiątkową In honorem Jan Zwiazek, by uhonorować znanego historyka, Jana Związka, w której podkreślono Jego rolę jako znaczącego historyka, którego dorobek i zasługi dla nauki wpisały się w historiografię Kościoła katolickiego w Polsce. Obecnie, gdy Ksiądz Profesor kończy pracę dydaktyczną w Papieskiej Akademii Teologicznej w Krakowie, chcemy przybliżyć Szacowną Osobę i jej dorobek naukowy.

Jan Związek urodził się 6 grudnia 1937 r. we wsi Młynki w powiecie wieluńskim, w byłym województwie łódzkim. Jego rodzice Szczepan i Anastazja z d. Kiedos byli właścicielami niewielkiego gospodarstwa rolnego. Gdy podczas II wojny światowej jego rodzice zostali przez hitlerowców wywiezieni na roboty do Niemiec, emocjonalnie związał się z najbliższymi krewnymi. Z domu rodzinnego wyniósł głęboką religijność, patriotyzm i umiłowanie tradycji narodowej oraz życzliwość wobec ludzi. Po zakończeniu działań wojennych uczęszczał do szkół podstawowych - najpierw w Kabałach, potem w Załęczu Małym. W roku 1952 wstapił do Niższego Seminarium Duchownego w Częstochowie; w 1956 roku jako eksternista w Liceum im. R. Traugutta w Częstochowie otrzymał świadectwo dojrzałości. Bezpośrednio po ukończeniu szkoły średniej rozpoczął studia filozoficzno-teologiczne w Częstochowskim Seminarium Duchownym w Krakowie. Jako kleryk podczas wakacji nie stronił od fizycznej pracy na roli, pogłębiając jednocześnie zdobytą wiedzę, szczególnie w zakresie historii Kościoła powszechnego. Święcenia kapłańskie otrzymał 29 czerwca 1961 r. w Częstochowie z rąk biskupa Zdzisława Golińskiego. 
Ukończenie studiów seminaryjnych $\mathrm{z}$ wyróżnieniem zaowocowało skierowaniem ks. J. Związka na studia specjalistyczne z zakresu historii Kościoła na Wydziale Teologicznym KUL w Lublinie. Stopień magistra teologii uzyskał w roku 1964 na podstawie pracy pt. Kazania niedzielne Mikotaja z Wilkowiecka, napisanej pod kierunkiem ks. prof. dr. hab. Mieczysława Żywczyńskiego.

$\mathrm{Z}$ uwagi na naglące potrzeby personalne $\mathrm{w}$ diecezji częstochowskiej ks. Związek w czerwcu 1965 r. został odwołany ze studiów. Powrócił do swojej diecezji, by przyjąc nominację na nauczyciela religii i propedeutyki filozofii marksistowskiej w Niższym Seminarium Duchownym w Częstochowie. Rok później dodatkowo powierzono mu stanowisko zastępcy redaktora naczelnego „Częstochowskich Wiadomości Diecezjalnych”. Nadal jednak pogłębiał zainteresowania naukowe z zakresu historii Kościoła.

Stopień doktora historii kościoła otrzymał w roku 1969 na Wydziale Teologicznym KUL na podstawie rozprawy pt. Katolickie poglady polityczno-społeczne w Polsce na przełomie XVI $i$ XVII wieku w świetle kazań, również napisanej pod kierunkiem ks. prof. dr. hab. M. Żywczyńskiego.

W tym samym roku rozpoczął prace jako archiwariusz w Archiwum Diecezjalnym w Częstochowie, co później zaowocowało kompetentnym warsztatem naukowym niezbędnym do prowadzenia własnych badań historycznych. Osobowość i rozwój naukowy wykładowcy, wychowawcy, redaktora i archiwisty z uwagą śledziły władze duchowne. W r. 1970 ks. Związkowi powierzono wykłady z zakresu metodologii nauk, patrologii i historii Kościoła w Częstochowskim Seminarium Duchownym w Krakowie i w Instytucie Teologicznym w Częstochowie. W 1975 r. został przyjęty jako członek - współpracownik do grona elitarnego Towarzystwa Naukowego KUL w Lublinie. Miarą naukowego autorytetu ks. Związka było powierzenie mu w r. 1979 prowadzenia wykładów z historii Kościoła w Wyższym Seminarium Duchownym OO. Franciszkanów w Krakowie. 17 listopada mianowano go dyrektorem Archiwum Diecezjalnego w Częstochowie. Mając ułatwiony dostęp do zasobów archiwalnych, już w następnym roku opublikował 8 artykułów naukowych. Odtąd jego dorobek naukowy systematycznie się powiększał.

Od momentu otrzymania stopnia naukowego doktora habilitowanego teologii w zakresie historii Kościoła w roku 1984, na podstawie rozprawy nt. Dzieje diecezji częstochowskiej w okresie II Rzeczypospolitej na Wydziale Teologicznym KUL w Lublinie przed ks. J. Związkiem pojawiły się możliwości jeszcze szerszego udziału w życiu naukowym kraju. Już jako rektor Częstochowskiego Seminarium Duchownego w Krakowie w roku akademickim 1986/1987 został zatrudniony na stanowisku docenta na Wydziale Historii Kościoła Papieskiej Akademii Teologicznej w Krakowie, gdzie przez dwie kadencje pełnił także obowiazki prodziekana oraz był członkiem senackiej Komisji Regulaminowej. W 1990 r. przyjął również propozycję prowadzenia wykładów z zakresu historii nowożytnej w Wyższej Szkole Pedagogicznej w Częstochowie, oraz z zakresu historii Kościoła i patrologii w seminariach zakonnych paulinów i bernardynów w Krakowie. Te specyficzne gremia studentów wymagają 
innego podejścia i odmiennego rozłożenia akcentów dydaktyczno-pedagogicznych; profesjonalizm ks. J. Związka doceniło wiele roczników słuchaczy.

Dysponujący dużym autorytetem naukowym ks. Jan Zwiazzek w roku 1991 został mianowany profesorem nadzwyczajnym na Wydziale Historii Kościoła Papieskiej Akademii Teologicznej w Krakowie, a rok później powierzono mu stanowisko profesora nadzwyczajnego w Instytucie Filozoficzno-Historycznym Wyższej Szkoły Pedagogicznej w Częstochowie. Wcześniej (1991) powołano go na członka Komisji Historycznej Polskiej Akademii Nauk - Oddział w Katowicach oraz został członkiem - korespondentem Towarzystwa Naukowego wydziału Teologicznego Katolickiego Uniwersytetu Lubelskiego.

W r. 1992 wojewoda częstochowski za zasługi dla naukowego środowiska częstochowskiego i popularyzację wiedzy o regionie mianował ks. prof. dr. hab. J. Związka stałym członkiem Zespołu Doradców Wojewody, w którym pełni funkcję relatora w zakresie historii $w$ aspekcie analizy współczesnych zjawisk społecznych w regionie częstochowskim. W kolejnym roku ks. prof. dr hab. J. Związek ograniczył działalność dydaktyczna, zrzekł się funkcji organizatorskich, koncentrując się na działalności naukowo-badawczej i pisarskiej.

Prowadząc bardzo usystematyzowany tryb życia podporządkowany rozwijaniu wartości osobowych i permanentnym badaniom naukowym, ks. Jan Związek starannie zakreślał zakres swoich badań naukowych. Chronologicznie są one bardzo rozległe, ponieważ obejmują XIV-XX wiek. Ksiądz Związek, który od początku swej pracy dydaktyczno-naukowej związał się z Wydziałem Historii Kościoła Papieskiej Akademii Teologicznej w Krakowie w sposób znaczący wpisał się w rozwój tegoż Wydziału. Praca dydaktyczna ks. Związka zaowocowała napisaniem pod jego kierunkiem ok. 150 prac magisterskich, 16 prac licencjackich oraz 8 prac doktorskich. W roku 1998 między innymi ks. Związek otrzymał na Wydziale Teologicznym Papieskiej Akademii Teologicznej w Krakowie tytuł naukowy profesora nauk teologicznych, a 11 stycznia $2000 \mathrm{r}$. w tej samej uczelni został mianowany profesorem zwyczajnym nauk teologicznych. Dzięki pracy naukowej ks. J. Zwiazka Wydział Historii Kościoła Papieskiej Akademii Teologicznej w Krakowie wpisał się w świadomość i funkcjonowanie badań historycznych w Polsce, dotyczących szczególnie Kościoła

Zakres rejonów badawczych ks. prof. dr. hab. J. Związka ulegał ciagłemu poszerzaniu $\mathrm{z}$ uwagi na publikacje przedstawiające wiele nowych, nieraz pionierskich zagadnień, szczególnie dotyczących przejawów życia religijno-społecznego Kościoła częstochowskiego. Zaznaczają się one na kilku płaszczyznach twórczości historycznej. Ksiądz prof. J. Związek jest autorem wielu haseł encyklopedycznych, wymagających szerokiej wiedzy o charakterze interdyscyplinarnym i przestrzegania zdyscyplinowanych form leksykograficznych. Prace ks. prof. J. Związka nawiązują do szerokiej literatury przedmiotu, zawierają nie tylko wątki historyczne, ale i teologiczne. Osobnym zakresem badawczym twórczości naukowej ks. prof. J. Związka są lata najnowsze, z wątkiem martyrologii wojennej i powojennej, będące skutkiem funkcjonowania systemów totalitarnych. Dzięki tym publikacjom ks. prof. Związek nie tylko zdołał poszerzyć perspektywę dziejów, ale także umoźliwił wielu młodym ludziom zrozu- 
mienie trudnych stuleci i zachodzących wówczas procesów, których świadkowie sami do końca nie byli świadomi. Ksiądz prof. Związek wykazał się zmysłem syntezy i umiejętnością akcentowania najbardziej istotnych wniosków.

Wszystkie rodzaje i formy działalności ks. prof. dr. hab. J. Związka są rezultatem Jego przymiotów osobowych. Spośród nich na czoło wybijają się dwie charakterystyczne cechy: pracowitość $\mathrm{i}$ troska o nieustanne pogłębianie formacji naukowej i kulturowej. Jest promotorem wartości humanistycznych w całej swej działalności dydaktyczno-naukowej i badawczej. To zaś pozwala żywić nadzieję, iż Szanowny Jubilat nadal będzie podejmował wysiłek twórczy, pomocny w przyporządkowaniu naturalnych celów Absolutowi. 